\title{
SOCIAL RESPONSIBLE BUSINESS PRACTICES IN BULGARIA: CHANGE IN ORGANIZATIONAL CULTURE
}

\author{
I. Slavova* \\ Department of Marketing and Strategic Planning, University of National and World Economy, \\ Sofia, Bulgaria
}

\begin{abstract}
The growing challenges to business, connected to accelerated globalization, increasing environmental protection and decreasing poverty, change the role of business in society and make corporate social responsibility (CSR) a strong and irreversible part of more and more companies' corporate actions. Socially responsible attitude is: changing corporate values, modeling behavior, transforming personal positions in accordance with individual and personal interests - a process of integrating CSR into organizational culture.

The main research question in this report is: Do firms operating in the Bulgarian market integrate CSR into their organizational culture?

The survey includes three aspects:

- $\quad$ First, a discussion on the concept of CSR and the different definitions for organizational culture; as well as revealing the connection between CSR and organizational culture.

- $\quad$ Second, presenting different models of CSR that implicitly connect corporate social initiatives and different types of business responsibilities with the beliefs, attitudes and corporate values.

- Third, implementing the benchmarking approach. The cultural change model towards sustainability of global carpet producer Interface, Inc. is used as a framework for studying the process of CSR integration into the organizational culture of companies operating in the Bulgarian market.
\end{abstract}

Key words: corporate social responsibility, organizational culture, benchmarking approach

\section{INTRODUCION}

The idea of corporate social responsibility (CSR) has been developed for many years and its concept is represented in many different ways (1-5). For over a decade the understanding that CSR is beyond the regulated by law traditional business responsibilities has predominated and in most definitions for CSR the voluntary principle of carrying out socially responsible initiatives is underlined. In the EU's new CSR strategy the concept of CSR is significantly expanded and it is defined as "a responsibility of the companies to their influence on society" (6, p.6). This is a starting point for the nature of CSR in the present study.

In different countries business, as well as all separate companies conduct different socially responsible behavior, implement different

\footnotetext{
${ }^{*}$ Correspondence to: Irena Slavova, Department of Marketing and Strategic Planning, University of National and World Economy, Sofia, email:irenaslavova@yahoo.com
}

policies, initiatives and forms of accountancy.

Among the many factors that influence the way in which companies realize CSR is culture as an element of the environment in which firms operate, as well as the company's culture - the beliefs, values and adjustments that form its identity.

In the following article the connection between CSR and organizational culture is studied. The conducted short literature overview and the presented CSR models show different perspectives on the nature and interaction between CSR and organizational culture. The thesis is defined that CSR is part of organizational culture when the internal business processes and the criteria for making decisions, as well as the actions of workers and employees, reflect the adopted corporate values connected to the environment and social sustainability.

The practices of leading companies show that integrating CSR into organizational culture is a 
long, dynamic and continuous process. The conducted practical survey outlines what stage of this process companies in Bulgaria are at. The status of companies operating in the Bulgarian market regarding the stages of CSR integration into organizational culture is defined and analyzed on the basis of the benchmarking approach (Interface, Inc.'s model - one of the best global practices for change towards a sustainability culture) and the results of a CSR survey for university project "CSR in Bulgaria - Part of European Social Practices" (7)

\section{CSR AND ORGANIZATIONAL CULTURE}

In academic literature culture is a subject of numerous surveys, with different authors focusing on different aspects of its nature. Culture is most often looked at as a component of the environment in which the company operates and, along with the economic, social, political, technological and other factors, influences the development of firms, as well as the decisions and actions of managers (8). Bird \& Smucker (9) emphasize the necessity for acknowledging cultural differences when firms define their CSR policies in different countries, as well as communications with stakeholders.

Trice and Beyer also link culture to the environment because organizational culture is a collective answer to insecurity and chaos (10). According to Schein, organizational culture is a model of basic suggestions, invented, discovered and developed by a certain group of people so that the organization can manage arising problems when it comes to external adaptation and internal integration (11). When this model works well enough, it is considered to be valid and it therefore has to be passed on to the new members of the organization as a correct way of how they think, feel and perceive arising problems. In this context, Kotter \& Heskett determine that culture can significantly influence the effectiveness of organizations because it helps the organization foresee or adapt to changes in the environment or it interferes with its adaptation (12).

Hofstede H., who studies cultural differences between individual sides based on certain key dimensions, defines culture as "a collective programming of the mind, which differentiates the members of one group or a category of people from another" and it includes a system of values, which are among the most constructive elements of culture (13,p.6). In specialized literature, even though it is defined differently, organizational culture is most often associated with shared values, beliefs and attitudes of a group of people or a certain organization. And this system of shared values and beliefs, along with the principal assumptions, which are created by leaders and shared by employees (14) distinguishes one organization from another.

Based on the short literature survey about the purposes of the present study, we bring out the following definition for organizational culture - a composition of shared values, beliefs, behavior and practices that build the organizational identity and allow the organization to manage internal and external challenges.

At present, more and more organizations are sharing the values of CSR and incorporate it into their own organizational culture. By turning the concept of corporate social responsibility into organizational practices, corporations have managed to build a CSR culture. It is assumed that the personal beliefs of managers and their engagement to protecting the environment and achieving social sustainability have a specific role in forming and maintaining CSR culture. According to Duarte CSR culture is subjective interpretations of ideas/beliefs and concrete permanent actions caused by the idea of social responsibility (15). The same author considers that most organizations have started incorporating CSR into their organizational culture, and in some cases this new formula has begun dominating in wide culture and organizational culture becomes "CSR culture" (15). Hancock also underlines the significance of organizational values and their role in creating CSR culture (16). He explains the origin and nature of CSR culture as stresses that $C S R$ culture fundamentally originates from and is created by values, not financial interests (instead of being a purely financial operation) and it always includes a systematic and widespread change in the way companies do business; from hiring human resources through production processes and relationships with suppliers (16). In order to integrate CSR into organizational culture CSR policies must be built in order to support the reputation and commitment to stakeholders in conjunction with internal business strategies and decisions led by social and ecological principles. 


\section{CSR MODELS}

There are different CSR models, which implicitly connect corporate social initiatives/practices and different types of business responsibilities to the beliefs, attitudes and values of the company, i.e. its organizational culture.

The first conceptual CSR model was created by Carroll (17) and it has three dimensions: corporate responsibilities, social business issues and corporate decisions. There are four types of corporate responsibilities - economic, legal, ethical and philanthropic (the order of these four types shows the relative meaning of each type). Social business issues can include different themes like labor standards, human rights, protecting the environment and fighting corruption, which are connected to the four types of responsibilities. Corporate activities represent certain common response models (i.e. reactive, protective, adaptive and proactive). Depending on these four types of corporate responsibilities, every company chooses the respective social issues connected to CSR, for which it takes specific corporate actions. In other words, responsibilities lead to the firm's responses in regards to specific social issues, partially depending on the seriousness of the issues perceived by society. It is necessary to note that these issues and their relative "significance" can be different to business and society and it can change with time. Therefore, this model helps managers get a clearer idea of the social problems they face as well as plan their actions aimed at improving or solving the arising social problems.

In their attempt to give meaning to a CSR model, Wartick \& Cochran (18) redefine Carroll's model based on the belief that a company's culture is the basis on which it will formulate and manage its social responsibilities. These authors offer another three-dimensional model of principles, policies and processes or the 3P CSR Model. They accept Jones's view (19) that CSR is not a composition of results, but a developing process (i.e. analysis, debates and modification) regulated by officially incorporated principles and policies.

At a later stage Wood (20) makes additions to the two three-dimensional models by emphasizing results or the implementation of CSR initiatives. In our opinion, the three models can be considered to be fundamental because they clarify the connection between the CSR principles, the conducted policies and the necessity for carrying out CS initiatives, as well as reporting the specific results of these initiatives. These models reflect the idea of an integrated CSR culture in one form or another. At present, academic society and business leaders support the belief that CSR's true worth and sustainability are realized only when they are incorporated into the company's organizational policy. Efforts are directed towards developing and implementing models that will showcase the process of incorporating CSR into organizational culture. For example, the Network for Business Sustainability and the Canadian Business for Social Responsibility recognize in their forum business leaders' need for a clear framework for sustainability/CSR in organizational culture. Tima Bansal's model for dynamic organization has been accepted as such a framework because it emphasizes the mutual connection and interdependence of the five elements in which CSR must be integrated: strategy, structure, processes, people, prizes (21)

The process of incorporating CSR in organizational culture is long and dynamic, and every company's path to sustainability is unique. In spite of that, exceptionally valuable is the experience of leading companies that have accepted and achieved a reforming change towards sustainability and it is an element of their corporate culture. Interface, Inc.'s model for cultural sustainability is considered a good global practice. The experience of the large American company for flooring production Interface, Inc. shows that cultural change is an evolution in top management beliefs, a long and dynamic process that goes through different stages and each stage requires the implementation of specific strategic decisions (22).

\section{Interface, Inc.'s Cultural Change Model}

Cultural transformation goes through five stages; at each stage strategic decisions are made that support the evolution in the belief system. Evolution in the belief system in time begins with a transition from skepticism to understanding, which transforms into a belief, then into obligation and finally it grows into commitment. Evolution in the belief system is realized consecutively in time, in accordance with the different stages of transformative change (awakening, maturity, metamorphosis, CSR integration into organizational culture and commitment). The interaction between these unifying factors is supported with strategic decisions (vision, road map, integration of 
sustainability/CSR in all structures of the organization, continuing integration and influence on others), which make the real process of cultural change possible.

\section{Characteristics of the Stages of Cultural Change}

First stage: Awakening

Evolution in beliefs: from skepticism to understanding

Strategic decision: defining a vision

In this first stage (awakening), the company has to overcome the skepticism for CSR and define its vision regarding its socially responsible behavior. The motives for realizing and accepting the necessity for CSR can be different and they are examined in numerous publications. ${ }^{1}(5)$.

At this stage it is important to overcome the skepticism for CSR; top management's commitment to grow into an expression for the company's mission or vision, as well as forming social policies in the field of environment too.

\section{Second stage: Maturity \\ Evolution in beliefs: from understanding to conviction}

Strategic decision: creating a road map After defining its views regarding its social and environmental responsibilities the company has to decide how to turn this vision into action. A process of planning is realized developing a "road map of action" (in accordance with Interface, Inc.'s terminology), which usually includes aims, activities (initiatives), deadlines, resource distribution, metrics.

Third stage: Metamorphosis

Evolution in beliefs: from conviction to obligation

Strategic decision: aligning the organization

During this stage, the company should to integrate sustainability/CSR into all structures of the organization. Once "the road map and the first prototypes" are made, the harder process of changes in the company begins - a creative destruction of rooted ways of thinking and processes is required. CSR has to be widespread, integrated and institutionalized into corporate systems, structures and processes.

Fourth stage: Emergence / Incorporating CSR into organizational culture

\footnotetext{
${ }^{1}$ The motives for realizing CSR are not a subject of examination in the present article.
}

Evolution in beliefs: from obligation to engagement

Strategic decision: ongoing integration

Well-defined indicators through which the accomplished results are measured and the feedback regarding the finished work is realized have a defining meaning for the continuous process of integrating CSR into organizational culture.

\section{Fifth stage: Engagement}

Evolution in beliefs: Commitment

Strategic decision: Influence on others

Commitment to CSR/sustainability has to be a permanent task. The presented model shows that the process' stages are continuous and repetitive, with knowledge and innovations getting deeper and deeper at each stage of the spiral. When an organization becomes more committed/attached to sustainability, training and its influence on others becomes an important part of the process of cultural change.

\section{SOCIALLY RESPONSIBLE BUSINESS PRACTICES IN BULGARIA: CHANGE OF ORANIZATIONAL CULTURE}

In this part of the article an answer is given to the main research question: do the firms operating on the Bulgarian market integrate CSR into their organizational culture?

\section{Research methodology}

In order to answer the research question, the benchmarking approach is applied. Using one of the best global practices for change towards a culture of sustainability (the aforementioned Interface, Inc. model) allows determination of the status of firms operating on the Bulgarian market with regard to the stages of integrating CSR in organizational culture. For this purpose, results from the CSR survey for university project "CSR in Bulgaria - Part of European Social Practices" (7) will be used:

First, results from a content analysis based on a study of the websites of firms operating in the Bulgarian market - of the 175 researched firms that realize different economic activities, 65 of them realize corporate social initiatives; corporate social initiatives such as a standalone CSR column are either posted on their web pages, or they are shown on the news and in press messages. Through their websites, companies represent their corporate social responsibility individually as well as the impression that the company's management creates as a commitment to different stakeholders with their public behavior. Websites are targeted towards a wide range of 
stakeholders and they are therefore logical sources of information for studying the firm's attitude towards CSR (23).

Second, results from an empirical study of business in Bulgaria - 200 firms have been are studied, $80 \%$ of which are representatives of small and medium enterprises. They complement the idea for business CSR in Bulgaria, more specifically the views and attitudes of small and medium businesses in Bulgaria (these are companies that do not have web sites with such information and they do not actively carry out corporate social initiatives).

\section{Analyses and research results: integrating CSR into the organizational culture of the businesses in Bulgaria}

Companies in Bulgaria are in a different stage of integrating socially responsible practices into their organizational culture.

First stage: Awakening. The majority of companies operating in the Bulgarian market are in the first stage ("awakening") of Interface, Inc.'s benchmarking model. A change in top management beliefs is observed - from skepticism regarding CSR the necessity for realizing such initiatives is realized and this view is expressed through the statement for the company's mission or vision, as well as through the formation of policies, primarily in the area of environment and employees, without realizing any concrete socially responsible initiatives. In accordance with the information provided by web pages, eight companies fall here: A and D Commercial Ltd. (mineral and non-mineral soft drinks and dining water producer); Voditsa Bottling Ltd. (a bottling company whose primary activity is bottling, distribution and sale of natural mineral water under the "Voditsa" trademark); Sofia - BT, JSC - a company that makes tobacco products; Bulgarian Sugar 2002 Ltd.; Zebra JSC (a Bulgarian company that produces trapezoidal straps, rubber plates, flooring and other rubber and rubber-metal products); Continvest Ltd. (a company that produces liquid and hard aluminum sulphate, etc.); Agria S.A. (a plant protection products manufacturer); KAI Group (a ceramic tiles and granite manufacturer).

In this first stage of transition towards a change in organizational culture we include the companies that list social commitment in their mission statement or have defined policies. They carry out single social initiatives, primarily donation (monetary) and sponsorship. Such initiatives have been observed primarily in the past few years (since 2012) and they are not connected to the company's activity; the donations are scattered among different causes. There is still a gap between concepts and actions. There are no strategic decisions to support the views about the necessity for socially responsible practices. We place sixteen firms here: Aspasia-92 Ltd. (a Bulgarian company specializing in the production and sale of soft drinks); Mikhalkovo JSC (a producer of bottled mineral water); Bottling Company Gorna Banya Ltd. (a producer of bottled mineral and dining water and soda drinks); Bottling Company Hissar; Domain Boyar (a producer and exporter of Bulgarian wine); Vinprom Peshtera JSC; Compass Ltd. (a Bulgarian company specializing in the production of sterilized meat and vegetable products); Deroni JSC; Olineza Ltd.; Bella Bulgaria - production of food-stuffs; Delikates $2 \mathrm{Ltd}$; Pobeda JSC, Mini Maritsa-East JSC, TEP Maritsa-East 2 JSC, NPP Kozloduy JSC, Refan Bulgaria Ltd.

At the first stage of cultural change are all companies that participated in the empirical survey. Business in Bulgaria has a positive attitude towards implementing CSR, however, small and medium enterprises do not know the different forms of corporate social initiatives and, above all, associates CSR with donations; and the benefits of carrying out such initiatives are associated with improving the firm's image. Second stage: Maturity. CSR transforms from views to convictions, which are supported by strategic decisions - creating a road map. There are companies that are already making strategic decisions in support of their beliefs about the necessity for carrying out CSR. This is indicated by the implementation of different forms of corporate social initiatives which are beneficial for both society and the company; stakeholders are different. These companies carry out regular and long-term corporate social initiatives and it can be expected that they will continue these activities in the future, while the choice of a theme and their planning will be connected to the company's main activity. Nine firms can be placed here: Devin JSC; Craft Foods Bulgaria JSC; United Dairy Company JSC; Danone Serdika JSC, Nestle Bulgaria JSC, Kaolin JSC, Aurubis Bulgaria, Aroma JSC, Lukoil Neftochim Burgas JSC, KCM JSC.

Third stage (metamorphosis) and fourth stage (ongoing integration). In accordance with the stages of the model used for benchmarking, in these stages firms integrate CSR in all 
structures of the organization (third stage); the views of these firms' top management have transformed from obligation into commitment and they carry out an uninterrupted process of CSR integration into structures, processes, systems; measuring and reporting the results (fourth stage).

Research shows that the Bulgarian market is an operating ground for companies which can be considered to be in these stages of incorporating CSR into the organizational culture. Those are primarily firms, which are part of global companies implementing the policies and strategies of the parent company in Bulgaria and have a built CSR culture.

Our reasons for this are the results from the conducted web-based content analysis, which determined that nineteen firms carry out complex and long-term CSR initiatives; realize a process of planning, execution and evaluating the strategies and programs for CSR with concrete metrics. CSR is integrated in corporate management. Most of them have built structural units for CSR. There is a wide range of stakeholders whose interests satisfy the firms. The choice of a theme is made in different forms of CSR initiatives. Among them are Coca-Cola HBC Bulgaria, Zagorka JSC, Karlsberg Bulgaria, AstraZeneca, Chaika Farma JSC, Borima JSC, M-Tel, Vivacom, Globul, Mine-Enriching Complex AssarellMedet JSC, Dundee Precious Metals Chelopech, Overgas Inc. JSC, Sviloza JSC, Polygraphic Group Demaks, MONBAT JSC, Holcim Bulgaria, KCM JSC, Vaptsarov Holding JSC.

The present survey does not outline companies that can be considered to be in the fifth stage of Interface Inc.'s model for cultural change. The number of companies that strive to pass on their experience and attract other firms (primarily small and medium enterprises) towards implementing CSR is insignificant. The companies that are members of the Association Global Compact Network Bulgaria ( members the UN Global Compact) are already taking their first steps in that direction.

\section{CONCLUSION}

A company's culture is the basis on which it formulates and manages its social responsibilities. The essential questions are how and through what actions is organizational culture (the values connected to the environment and social sustainability) reflected into everyday business practices. Therefore, this is the point where organizational culture and CSR link.

The conducted study shows that integrating CSR into organizational culture is a long and dynamic process that goes through different stages; it mandates evolution into the beliefs of top management and making strategic decisions at every step of this transformation. Following the Interface, Inc. model as a framework for study, we have determined that companies in Bulgaria are at different stages of cultural change towards sustainability/CSR. The majority of studied firms operating in the Bulgarian market are in the early stages of change, and only large companies in Bulgaria, which are primarily part of transnational corporations, have a built CSR culture.

\section{REFERENCES}

1. Carroll, A. B. Ethical Challenges for Business in the New Millennium: Corporate Social Responsibility and Models of Management Morality, Business Ethics Quarterly, Vol. 10 No. 1, pp. 33-42, 2000.

2. Dahlsrud A., How Corporate Social Responsibility is Defined: an Analysis of 37 Definitions, Corporate Social Responsibility and Environmental Management, Volume 15, Issue 1,pp. 1-62, 2008

3. Robins, F. The future of corporate social responsibility. Asian Business \& Management, vol. 4, pp. 95-115, 2005

4. Matten D, Moon J, "Implicit" and "explicit" CSR: A conceptual framework for a comparative understanding of corporate social responsibility" Academy of Management Review, 33 404-424, 2008

5. Porter, M., Kramer, M., Strategy and society: the link between competitive advantage and corporate social responsibility , Harvard Business Review, December, 2006

6. European Commission, A renewed EU strategy 2011-14 for Corporate Social Responsibility, Brussels, $\operatorname{COM}(2011) 681$ final, p.6, 2011

7. Славова, Ир., Банкова, Й., Иванов, Хр. Корпоративната социална отговорност в България - част от Европейските социални практики, Издателски комплекс, УНСС, С., 2014

8. Žitkus, L., Junevičius, A. Boundaries of Possible Solutions of Management Problems Caused by Cultural Interaction, Engineering Economics, 1, 51, p. 4449.2007 
9. Bird F., Smucker J. The Social Responsibilities of International Business Firms in Developing Areas, Journal of Business Ethics, 73, p. 1-9, 2007.

10.Trice, H., Beyer, J. The Cultures of Work Organizations. Englewood Cliffs, NJ: Prentice Hall, 1993.

11.Schein, E. H. Organizational Culture and Leadership, Jossey Bass Publishers, 1992.

12.Kotter, J. P., Heskett, J. L. Corporate culture and performance, New York: Free Press, 1992.

13.Хофстеде, Х., Култури и организации, Софтуер на ума, Изд. Класика и стил, С., 2001

14.O'Reilly, C., Chatman, J., \& Caldwell, D. People and organizational culture: A Q-sort approach to assessing person-organization fit, Academy of Management Journal, 34, 487-516, 1991.

15.Duarte, F. "Working with corporate social responsibility in Brazilian companies: the role of managers' values in the maintenance of CSR cultures", Journal of Business Ethics, 96(3), 355-368, 2010.

16. Hancock, K. „Employee Engagement Partnerships: Can They Contribute to the Development of an Integrated CSR

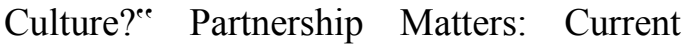
Issues in Cross-Sector Collaboration (3), 17-20, $2005 . \quad$ http:// www.cpi.cam.ac.uk/pdf/partnershipmatters 3.pdf.
17.Carroll, A.B. A three-dimensional conceptual model of corporate performance. Academy of Management Review, 4(4), 497-505, 1979.

18. Wartick S., Cochran P., The Evolution Of The Corporate Social Performance Model, The Academy Of Management Review, 10 (4), 758-769, 1985

19.Jones, T. (1995). 'Instrumental stakeholder theory: a synthesis of ethics and economics. Academy of Management Review, 20 (2), 404-437

20.Wood D. J. Corporate Social Performance Revisited. The Academy of Management Review, 16(4). 691-718, 1991

21. Embedding Sustainability in Organizational Culture, Framework and best Practices; Canadian Business for Social Responsibility , Network for Business Sustainability, $2010 \quad$ http://nbs.net/wpcontent/uploads/CultureReport_v4_F2.pdf Accessed, 10 May 2015

22. Anderson, R., Amodeo,M., Hartzfeld, J. Changing Business Cultures from Within, State of the World, Transforming Culture: From Consumerism to Sustainability, W.W. Norton \& Company, New York, Worldwatch Institute, 2010, pp. pp.96102

23.Esrock \& Leichty, A Model for Assessing Web Sites as Tools in Building Organizational-Public Relationships,1998, www.lamar.colostate.edu/pr./webrelationshi p Accessed, 20 June 2015 